\title{
Energy and Environmental Research Emphasizing Low-Rank Coal -- Task 5.1 Stability Issues
}

\section{Topical Report}

Chris M. Anderson

Mark A. Musich

Ray A. Dewall

John J. Richter

April 1995

Work Performed Under Contract No.: DE-FC21-93MC30097

For

U.S. Department of Energy

Office of Fossil Energy

Morgantown Energy Technology Center

Morgantown, West Virginia

By

University of North Dakota Grand Forks, North Dakota

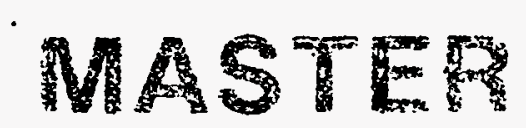

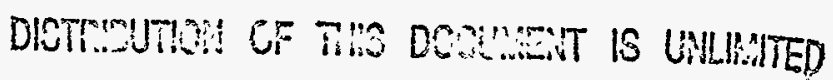




\title{
Energy and Environmental Research Emphasizing Low-Rank Coal -- Task 5.1 Stability Issues
}

\section{Topical Report}

\author{
Chris M. Anderson \\ Mark A. Musich \\ Ray A. Dewall \\ John J. Richter
}

Work Performed Under Contract No.: DE-FC21-93MC30097

For

U.S. Department of Energy

Office of Fossil Energy

Morgantown Energy Technology Center

P.O. Box 880

Morgantown, West Virginia 26507-0880

\author{
By \\ University of North Dakota \\ Energy and Environmental Research Center \\ P.O. Box 9018 \\ Grand Forks, North Dakota 58202-9018
}




\section{ACKNOWLEDGMENT}

This topical report was prepared with the support of the U.S. Department of Energy (DOE) Morgantown Energy Technology Center Cooperative Agreement No. DE-FC21-93MC30097. However, any opinions, findings, conclusions, or recommendations expressed herein are those of the author(s) and do not necessarily reflect the views of the DOE. 
LIST OF FIGURES $\ldots \ldots \ldots \ldots \ldots \ldots \ldots \ldots \ldots \ldots \ldots \ldots \ldots \ldots \ldots$ ii

LIST OF TABLES $\ldots \ldots \ldots \ldots \ldots \ldots \ldots \ldots \ldots \ldots \ldots \ldots \ldots \ldots \ldots \ldots \ldots \ldots$

EXECUTIVE SUMMARY $\ldots \ldots \ldots \ldots \ldots \ldots \ldots \ldots \ldots \ldots \ldots \ldots \ldots$ iii

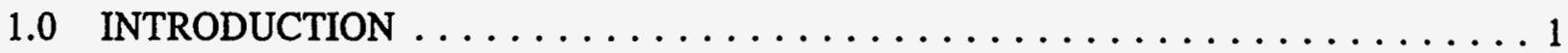

2.0 OBJECTIVES $\ldots \ldots \ldots \ldots \ldots \ldots \ldots \ldots \ldots \ldots \ldots \ldots \ldots \ldots \ldots \ldots \ldots \ldots \ldots \ldots \ldots$

3.0 EXPERIMENTAL PROCEDURE $\ldots \ldots \ldots \ldots \ldots \ldots \ldots \ldots \ldots \ldots \ldots \ldots \ldots \ldots \ldots$

3.1 Coal Preparation and Drying $\ldots \ldots \ldots \ldots \ldots \ldots \ldots \ldots \ldots \ldots \ldots \ldots \ldots \ldots \ldots \ldots \ldots \ldots$

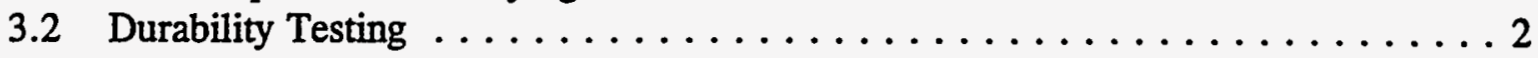

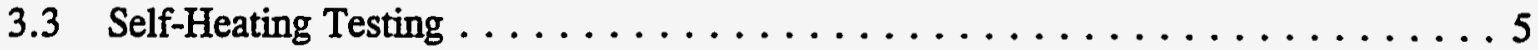

3.4 Equilibrium Moisture Testing $\ldots \ldots \ldots \ldots \ldots \ldots \ldots \ldots \ldots$

4.0 RESULTS $\ldots \ldots \ldots \ldots \ldots \ldots \ldots \ldots \ldots \ldots \ldots \ldots \ldots \ldots \ldots \ldots \ldots \ldots \ldots \ldots$

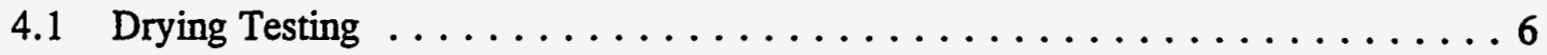

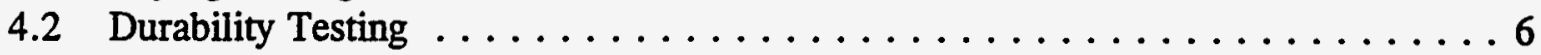

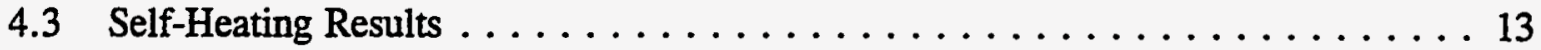

4.4 Moisture Reabsorption Results $\ldots \ldots \ldots \ldots \ldots \ldots \ldots \ldots \ldots \ldots$

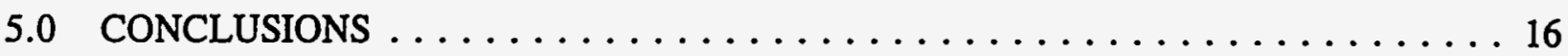

6.0 FUTURE WORK $\ldots \ldots \ldots \ldots \ldots \ldots \ldots \ldots \ldots \ldots \ldots \ldots \ldots \ldots \ldots \ldots \ldots \ldots$

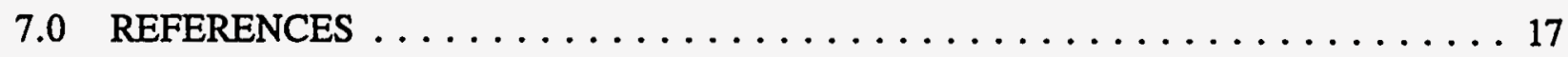

ASTM AND OTHER PROCEDURE DESCRIPTIONS $\ldots \ldots \ldots \ldots \ldots \ldots$ Appendix A 


\section{LIST OF FIGURES}

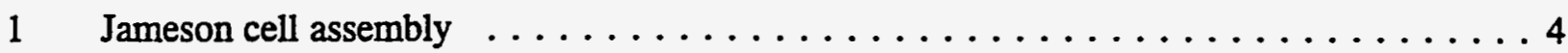

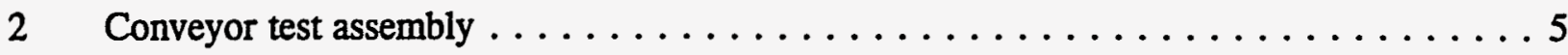

3 Tumble indices for raw, AD, HWD, and SSD Colstrip as a function of total revolutions $\ldots \ldots \ldots \ldots \ldots \ldots \ldots \ldots \ldots \ldots \ldots$

4 Jameson test results, moisture content versus tumbling time, for various Colstrip samples $\ldots \ldots \ldots \ldots \ldots \ldots \ldots \ldots \ldots \ldots \ldots \ldots \ldots$

5 Jameson test results, amount of fines versus tumbling time, for various Colstrip samples $\ldots \ldots \ldots \ldots \ldots \ldots \ldots \ldots \ldots \ldots \ldots \ldots$

6 Jameson test results for saturated and unsaturated Knife River samples $\ldots \ldots \ldots \ldots 12$

7 Dust concentration comparison $\ldots \ldots \ldots \ldots \ldots \ldots \ldots \ldots \ldots \ldots \ldots \ldots \ldots \ldots$

\section{LIST OF TABLES}

1 Average Friability Values of Different Coal Ranks $\ldots \ldots \ldots \ldots \ldots \ldots \ldots$

2 Proximate, Ultimate, and Heating Value for Raw, HWD, and SSD

Subbituminous and Lignite Coal $\ldots \ldots \ldots \ldots \ldots \ldots \ldots \ldots \ldots \ldots$

3 Hardgrove Index, Friabilities, and Dust Indices for Raw, AD, HWD, and SSD Subbituminous and Lignite Coals $\ldots \ldots \ldots \ldots \ldots \ldots \ldots \ldots$

4 Summary Information from Tumble Tests Conducted on Various Colstrip Samples . . . . . . . . . . . . . . . . . . 10

5 Summary Information from Tumbler and Conveyor Tests Conducted on Raw and Air-Dried Beulah Lignite Samples . . . . . . . . . . . . 10

6 Summary Information from Tumbler and Conveyor Tests Conducted on Raw Beulah Lignite Samples . . . . . . . . . . . . . . . . 14

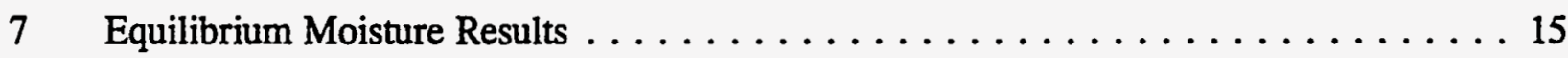




\section{STABMITY ISSUES}

\section{EXECUTIVE SUMMARY}

Low-sulfur subbituminous and lignite coals have high moisture content and, consequently, low heating value, leading to boiler derating in U.S. midwestern and eastern utilities as well as switching and/or blending coals to achieve $\mathrm{SO}_{2}$ compliance. In the drive to develop cost-effective coal-drying processes, coal developers have focused on heat content of the products and generally neglected the critical stability issues of friability and dusting, moisture reabsorption, and spontaneous heating. The Energy \& Environmental Research Center (EERC), in an effort to establish new standards for dried products, has used established methods and has developed new ones to evaluate the propensity of lump western coals, raw and dried, to produce dust and absorb water. Three drying methods-air, hydrothermal, and saturated steam-were used to generate lowmoisture upgraded products. New indices for dust generation and friability were determined to assess the effects of moisture removal and upgrading methodology on coal stability. Analysis of the dried coals using various strength tests indicated that the reduction in moisture made the lump coal unstable, yielding substantially higher dust and friability indices relative to those of the raw coals. 


\section{STABILITY ISSUES}

\subsection{INTRODUCTION}

The low-rank coal (LRC) upgrading technologies being developed include evaporative and nonevaporative drying and mild pyrolysis/gasification. An obstacle facing their development is the stability of the product with regard to dusting, moisture reabsorption, and spontaneous combustion. Because stability phenomena are often given only minor attention, the development of improved stability-testing methods was deemed a necessary and complementary component in the successful demonstration of upgrading technologies (1).

Friability, as measured by either the American Society for Testing and Materials (ASTM) drop-shatter test or tumbler test, has determined the LRCs to be the least friable. It has been previously reported that coal friability assumes a maximum of nearly $90 \%$ carbon (moisture- and ash-free basis) for high-rank coals, declining for lower-rank materials. Table 1 summarizes friability indices for various ranks of coal measured after tumbling the coal for 3 hours $(2,3)$. Friability for anthracite was $33 \%$, while low- and medium-volatile bituminous coal had the highest level at $70 \%$. Even though LRCs are reported to be less friable at only $12 \%$, they show a pronounced tendency to disintegrate on exposure to the weathering conditions that are not simulated in ASTM procedures. This effect was first reported by Parry in 1941 when a sample of subbituminous coal was air-dried in a coal bin (4). The sample showed an increase of $34 \%$ in friability after air drying 10 days and a further increase to a total of a $138 \%$ after 20 days of air drying. As these results indicate, slacking, like the handling of a friable coal, causes the formation of an excessive amount of fine material at the expense of the coarser sizes, thus decreasing the value of the coal for most uses. Slacking indices of $5 \%$ or less characterize bituminous coals, whereas values for lignite approach $100 \%$ (5).

No single test has been available to address the quality of coals to include attrition, coal weathering (slacking), shattering, and dusting properties of the fuel. In an effort to combine laboratory procedures with real-world application, a test loop was designed to assess the friability

\section{TABLE 1}

Average Friability Values of Different Coal Ranks

\begin{tabular}{lc}
\hline Coal Type & Friability, \% \\
\hline Anthracite & 33 \\
Low- and Medium-Volatile Bituminous & 70 \\
High-Volatile Bituminous & 43 \\
Subbiruminous A & 30 \\
Subbituminous B & 20 \\
Lignite & 12 \\
\hline
\end{tabular}


and dust issues associated with handling solid fuels. The conveyor system offers a method to continually monitor dust emissions and assess various dust suppression additives without conducting a full-scale field test. Establishing this system will provide an important link between research and commercial applications and extend EERC capabilities to better evaluate the integrity of upgraded fuel products.

\subsection{OBJECTIVES}

This program was established to assess the physical stability of as-received and upgraded low-rank coals based on dust generation, moisture reabsorption, and spontaneous combustion. The project-specific objectives were as follows:

- Develop improved methods for evaluating the physical stability of raw and dried coal samples.

- Correlate ASTM methods with modified procedures and understand their relationship or their appropriateness to real-world applications.

- Establish indices for dust-handling characteristics for various coal types and how they are impacted by current dust suppression methods (e.g., containment, stockpiling, dust collection devices, or suppression additives).

\subsection{EXPERIMENTAL PROCEDURE}

\subsection{Coal Preparation and Drying}

Coals processed in subsequent drying tests were sized to $12.7 \times 6.7 \mathrm{~mm}$ via stage crushing and bottom sizing. This size range was determined to be representative of upgraded coals produced by drying and pyrolysis processes currently in stages of development ranging from bench through demonstration scale $(3,4)$.

The three coal-drying methodologies tested include air drying, hydrothermal treatment, and saturated steam drying (SSD). Air drying was performed to observe the effects of lowtemperature, evaporative drying on coal stability. The drying period was extended, as necessary, until the desired moisture content was attained; the total coal moisture content was determined by ASTM Method D3173.

The hydrothermal drying processes (HWD and SSD) were performed to observe the effects of nonevaporative drying on coal stability. During HWD, the coal is totally immersed in the water phase, whereas during SSD, the coal is in contact with only the vapor phase (saturated steam). The systems and procedures for hydrothermal treatment are described elsewhere (6-8).

\subsection{Durability Testing}

Currently, four ASTM procedures are available to address the physical stability of coal or coal-derived products: D1412-86 (equilibrium moisture), D441-45 (tumbler test), D409-71 
(Hardgrove index), and D440-49 (drop-shatter test) (9). Summaries of each of the ASTM procedures can be found in Appendix A.

Tumble Test. A modified ASTM tumble test was developed to determine the relative friability and abrasiveness of the sized raw and treated coals during simulated handling. The main internal flights were adjusted to accommodate a smaller coal size, $12.7 \times 6.7 \mathrm{~mm}$. A more detailed presentation of the modified tumble test assembly and procedures can be found in Appendix A and elsewhere (7).

Prior to tumble testing, the weights of test coals retained on 9.5- and 6.7-mm screens were determined. These two screen fractions were recombined prior to tumble testing. Tumble tests were performed by varying rotational speed ( 40 to $80 \mathrm{rpm}$; ASTM $=40 \mathrm{rpm}$ ), coal charge (100 to 1000 grams; ASTM = 1000 grams), and total revolutions (600 to 14,$400 ;$ ASTM $=2400$ ). Tumbled coal samples were classified into seven size fractions ranging from $9.5 \mathrm{~mm}$ to $0.60 \mathrm{~mm}$. The weights of the feed and tumbled coal weight fractions were used to calculate the tumble index $\left(T_{i}\right)$, defined by Equation 1, for each screen size fraction:

$$
T_{i}=\left(W_{T}-W_{F}\right) \times\left(100 / W_{A}\right)
$$

where $W_{T}=$ Weight of tumbled coal for screen size $\mathrm{i}$, grams

$W_{F}=$ Weight of feed coal for screen size $i$, grams

$\mathrm{W}_{\mathrm{A}}=$ Weight of total feed coal for tumbler test, grams

This equation was derived to remove the effect of feed coal size and sample mass variations on tumble results, thus allowing comparison of different coal types. A negative tumble index reflects a net mass reduction for a particular coal size as a result of comminution; conversely, a positive tumble index reflects a net mass increase for a particular coal size due to comminution of larger particles. The sum of the numbers should be zero.

In addition to tumble indices, the screening results from tumble testing were converted to friability and dust indices. Background on the ASTM tumble tests and calculation of friability indices are presented elsewhere (9). The " $s$ " factor was calculated using Equation 2, and the friability indices were calculated using Equation 3. The former equation represents a modified method of calculating the " $\mathrm{s}$ " factor, which relates the fraction of coal on individual screens to the average feed coal size rather than that of the top screen only (ASTM procedure). Reference to an estimated average particle size more accurately reflects the variability of the feed coal. The sample's dust indices were determined similarly to ASTM procedures by simply measuring the weight percent of coal passing the 0.3-mm (50-mesh) screen.

$$
\mathrm{s}=\mathrm{wt} \%_{(\text {on screen) }} \times \mathrm{A}_{i s} / \mathrm{A}_{p}
$$

where $\quad A_{i s}=$ Average initial screen size

$A_{p}=$ Estimated average particle size of feed material

$$
\text { Friability }(\%)=100-\Sigma s
$$

Drop-Shatter Test. A modified ASTM D440 drop-shatter test was also used to determine the relative size stability and its complement, friability, via a method similar to the tumble test. 
Drop-shatter testing is used to estimate the ability of coal to withstand breakage when subjected to handling at the mine and during transit to the consumer. In this test, 50 grams (ASTM method requires 50 pounds, i.e., 22,700 grams) of raw or dried coal was classified to determine size distribution, recombined, and then dropped through a $1.83-\mathrm{m}(6-\mathrm{ft})$ section of polyvinyl chloride (PVC) pipe into a steel vessel with a $1 / 4$ in. thick bottom. Each coal sample was dropped 10 consecutive times, and classification was performed after the second, sixth, and tenth (final) drop.

Jameson Cell Testing. Coal durability testing was also performed using a modified Jameson cell developed at the University of Newcastle (Australia) (10). The Jameson unit consists of an ASTM tumble cell with an in-line dust collection system. The dust collection system includes a coal size inhibitor connected to a vacuum cleaner. Figure 1 illustrates the assembly. The vacuum pulls air across the tumbling bed of coal sample, simulating wind conditions at approximately $25 \mathrm{~km} / \mathrm{hr}$. Results are determined by sieve analysis, amount of dust collected by the vacuum cleaner bag, and the moisture content of periodic samples.

Conveyor Test Loop. The significance of the laboratory results from the ASTM D441 tumble test and from the pilot-scale testing was evaluated. Pilot-scale tests using larger quantities of test coal, were conducted to more accurately simulate actual handling operations to appreciate friability and slacking tendencies in one system. Pilot-scale performance testing was completed using a test loop consisting of various conveyors. Figure 2 shows the conveyor test assembly. The main equipment used for test setup consisted of four conveyors and a 76.2-cm-diameter vibrating screen. The speed of the conveyors used ranged from 0.4 to $1.2 \mathrm{~m} / \mathrm{s}$, creating an estimated loop time of about $30 \mathrm{~s}$. The loop features a drop point to simulate the coal loadout station and transfer areas. For example, a 5-min conveyor test involves transporting the coal 150 $\mathrm{m}$ and dropping the coal a total of $15 \mathrm{~m}$, which is comparable to transfer length and drop levels at utility stations.

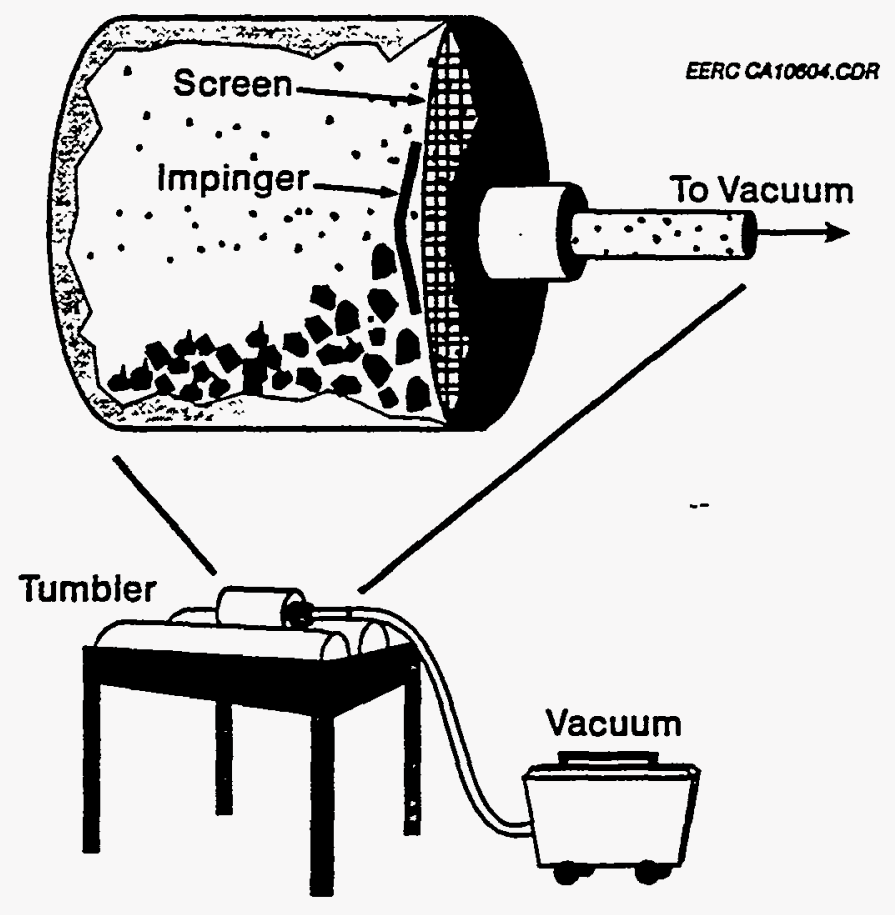

Figure 1. Jameson cell assembly. 


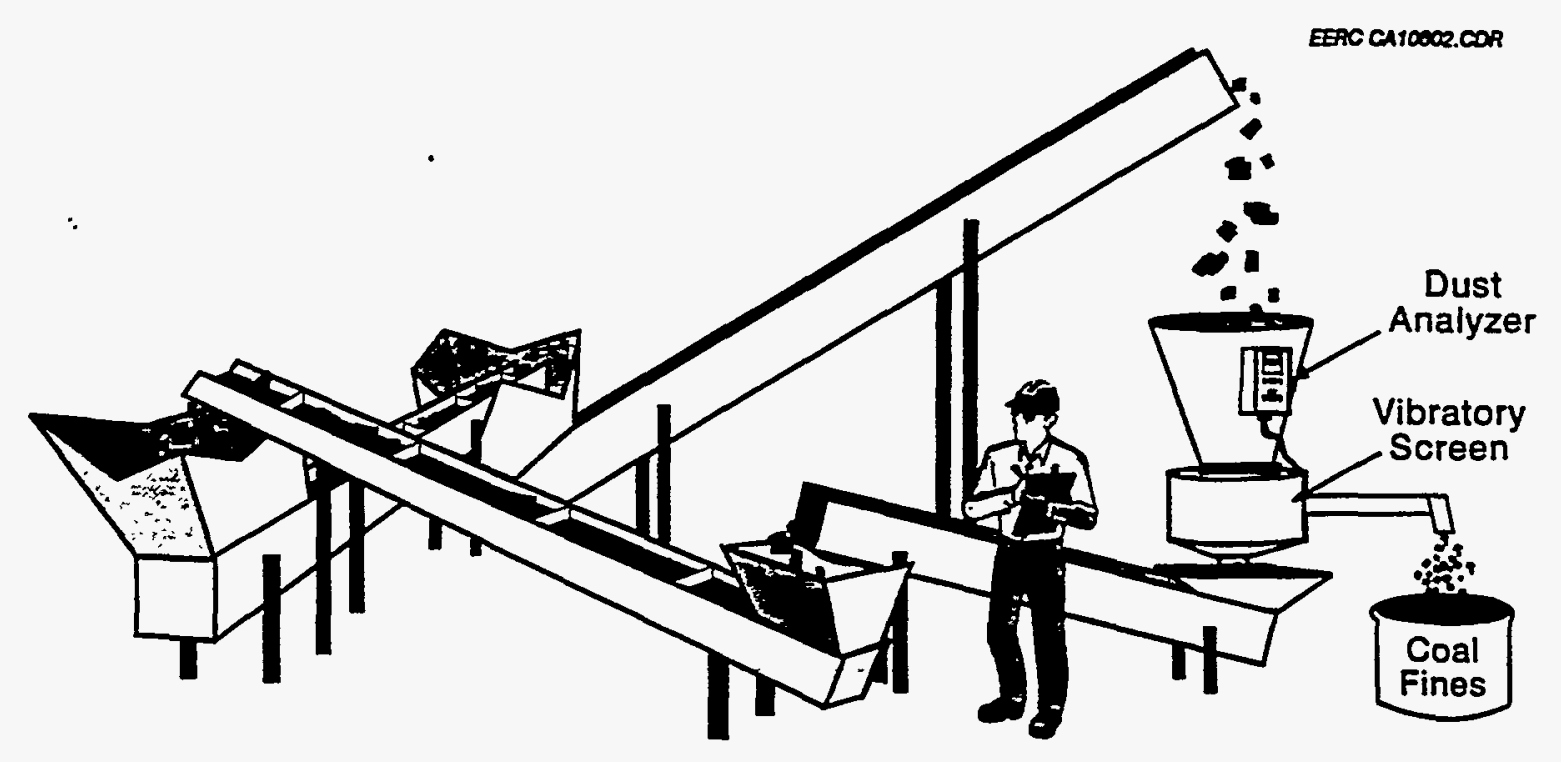

Figure 2. Conveyor test assembly.

Attached to the drop receiving tank is a real-time dust concentration analyzer that measures the level of fugitive, or nuisance, dust that occurs from dropping the coal sample $1.5 \mathrm{~m}$. Each set of conveyor walls was elevated to keep the coal particles from escaping the system as the coal was being transferred. A vibrating screen, used to remove -20 -mesh material, is located directly after the drop area. This screening step inhibits the loss of additional fugitive dust and provides a method to contain the fines in one location.

\subsection{Self-Heating Testing}

For research on self-heating tendencies of LRC and products, the Energy \& Environmental Research Center (EERC) is developing testing procedures following guidelines presented by the Bureau of Mines (11-13). The goal of the Bureau of Mines is to come up with a portable, inexpensive method to evaluate the self-heating tendencies of coal. After years of development, a test known as the sealed-flask test was identified. The experimental procedure consists of placing a nitrogen-dried coal sample in 1-pint glass containers equipped with a gas-sampling port and connected to a pressure-monitoring system. An increase in pressure in a sealed flask has been correlated against complex adiabatic test results, thus allowing self-heating estimates to be done easier and more cost-effective then previous methods. Monitoring pressure with pressure transducers for 3 to 7 days allows a minimum self-heating temperature to be calculated for the coal samples. 


\subsection{Equilibrium Moisture Testing}

Modifications to the ASTM D1412 equilibrium moisture procedure were investigated to observe dependence on particle size, sample preparation, and incubation period. A detailed summary of this ASTM procedure can be found in Appendix A. All equilibrium moisture tests were performed under a vacuum at $30^{\circ} \mathrm{C}$ and $96 \%$ to $97 \%$ relative humidity. The test chamber humidity was maintained by saturated potassium sulfate $\left(\mathrm{K}_{2} \mathrm{SO}_{4}\right)$ solution. The equilibrium moisture for each coal type was presented as the average of three determinations.

The applicability of the 3-day incubation period (ASTM D-1412, suggested for low-rank coals and coal products) was evaluated by two modified equilibrium moisture procedures. Coals were sized to the ASTM-specified $-1.2 \mathrm{~mm}$ ( $-16 \mathrm{mesh})$ prior to testing. The first modified equilibrium moisture test investigated the attainment of constant sample-weight as the indicator of equilibrium. The test procedure was further modified to include measurement of the initial moisture content of the ASTM D1412 prepared sample.

The effect of preincubation sample-preparation methods on the final- or equilibrium-moisture of raw or treated coals was evaluated by comparing the results for wetted samples (ASTM procedure) and surface-dry samples. The samples, sized to $12.7 \times 6.7 \mathrm{~mm}$, were incubated for 3 days, after which the moisture content was determined. Similarly, the effect of sample particle size on the final or equilibrium moisture of raw or treated coals was evaluated by comparing the results for lump coal samples and $-1.2-\mathrm{mm}$ samples.

\subsection{RESULTS}

\subsection{Drying Testing}

Hydrothermal drying tests were performed with three coals; Knife River lignite (North Dakota), Colstrip subbituminous (Montana), and Little Tonzona Creek subbituminous (Alaska). Saturated steam drying and hot-water drying were performed at $300^{\circ} \mathrm{C}$. Table 2 summarizes the proximate and ultimate analyses (equilibrium moisture basis) for the raw and dried coals. The changes in each coal caused by the drying processes included irreversible removal of moisture, enhancement of heating value, and reduction of oxygen content (via decarboxylation). The theoretical emissions of ash and $\mathrm{SO}_{2}(\mathrm{lb} / \mathrm{MMBtu})$ were 1$)$ significantly reduced for the Colstrip subbituminous; 2) significantly increased for the Knife River lignite; and 3) relatively unchanged for the Little Tonzona Creek subbituminous.

\subsection{Durability Testing}

Table 3 summarizes the results of durability tests on the three coals and dry coal products. Included are the friability and dust indices from the processing, tumbler, and drop-shatter testing. The test moistures and the hardgrove indices for each of the samples are also indicated in Table 3. Similarities were realized in drop-shatter and tumble friability data. However, substantially more fines were generated during tumbler tests for the same three Colstrip samples. This indicates that the tumble test had more attrition, and drop-shatter testing presented more of an impact test to the coal product. 


\section{TABLE 2}

Proximate, Ultimate, and Heating Value for

Raw, HWD, and SSD Subbituminous and Lignite Coal (equilibrium moisture basis)

\begin{tabular}{|c|c|c|c|c|c|c|c|c|c|}
\hline \multirow{2}{*}{$\begin{array}{l}\text { Coal: } \\
\text { Drying Type: }\end{array}$} & \multirow[b]{2}{*}{-} & \multicolumn{2}{|c|}{ Little Tonzona } & \multicolumn{3}{|c|}{ Colstrip } & \multicolumn{3}{|c|}{ Knife River } \\
\hline & & HWD & $\mathrm{SSD}^{2}$ & - & HWD & SSD & - & HW & SSD \\
\hline Equilibrium Moisture, wt\% & 31.0 & 11.1 & 9.5 & 25.3 & 9.3 & 8.6 & 35.1 & 15.0 & 12.6 \\
\hline \multicolumn{10}{|l|}{ Proximate, wt\% } \\
\hline Volatile Matter & 36.1 & 39.4 & 39.1 & 29.9 & 34.4 & 34.2 & 29.7 & 35.1 & 36.2 \\
\hline Fixed Carbon & 25.8 & 39.5 & 41.0 & 37.2 & 47.6 & 48.2 & 27.7 & 38.8 & 39.9 \\
\hline Ash & 7.1 & 10.0 & 10.4 & 7.6 & 8.7 & 9.0 & 7.5 & 11.1 & 11.3 \\
\hline \multicolumn{10}{|l|}{ Ultimate, wt\% } \\
\hline Hydrogen & 6.8 & 5.2 & 5.1 & 6.0 & 5.3 & 4.9 & 6.7 & 5.4 & 5.3 \\
\hline Carbon & 41.2 & 58.3 & 59.1 & 50.4 & 63.8 & 63.8 & 40.3 & 55.7 & 56.9 \\
\hline Nitrogen & 0.5 & 0.6 & 0.6 & 0.5 & 0.7 & 1.0 & 0.5 & 0.7 & 0.8 \\
\hline Sulfur & 1.1 & 1.3 & 1.2 & 0.8 & 0.8 & 0.7 & 0.9 & 1.4 & 1.4 \\
\hline Oxygen & 43.4 & 24.6 & 23.5 & 34.7 & 20.6 & 20.6 & 44.0 & 25.7 & 24.3 \\
\hline Ash & 7.1 & 10.0 & 10.4 & 7.6 & 8.8 & 9.0 & 7.5 & 11.1 & 11.3 \\
\hline $\begin{array}{l}\text { Heating Value, } \\
\text { Btu/lb }\end{array}$ & 7030 & 10,030 & 10,200 & 8550 & 10,850 & 10,830 & 6740 & 9400 & 9550 \\
\hline
\end{tabular}

Tumble Test. Prior to evaluation of dried coals, tumble tests were performed with sized, raw Colstrip subbituminous coal to determine appropriate values for several tumbling parameters: lifting shelf dimensions, mass of coal sample, tumbler speed, and total revolutions. Tests were first performed using two different lifting shelves at an ASTM specification tumbling speed of $40 \mathrm{rpm}$ and total revolutions of 2400. Friability and dust indices of raw coals tumbled with the ASTM specification lifting shelf (1.6-cm gap, $1.9-\mathrm{cm}$ ledge) were $30 \%$ to $50 \%$ lower than indices obtained when the same coals were tumbled with the modified lifting shelf. Tumbler testing also indicated a substantial increase in fines production as the revolutions increased, little difference in fines production as tumbler speed changed, and a proportional relationship between fines generated and the amount of coal used for the tumbler test. However, the repeatability of indices was adversely affected by a reduction in coal test quantity (100 grams versus 1000 grams) when the ASTM specification lifting shelf was used. Because of the limited amount of dried coals available for subsequent testing, the modified lifting shelf was considered necessary to assure sufficient test coal agitation and to achieve repeatability of indices.

Further, an evaluation of tumbling speed was performed on the raw, sized coals by comparing friability and dust indices obtained at $40 \mathrm{rpm}$ and 2400 revolutions (ASTM specifications) and $80 \mathrm{rpm}$ and 2400 revolutions. The indices were not substantially different; 


\section{TABLE 3}

Hardgrove Index, Friabilities, and Dust Indices for Raw, AD, HWD, and SSD Subbituminous and Lignite Coals

\begin{tabular}{|c|c|c|c|c|c|c|c|c|c|c|c|c|}
\hline \multirow{2}{*}{$\begin{array}{l}\text { Coal: } \\
\text { Drying Type: }\end{array}$} & \multirow[b]{2}{*}{ Raw } & \multicolumn{3}{|c|}{ Little Tonzona } & \multicolumn{4}{|c|}{ Colstrip } & \multirow[b]{2}{*}{ Raw } & \multicolumn{3}{|c|}{ Knife River } \\
\hline & & $\mathrm{AD}^{1}$ & HWD & SSD & Raw & $\mathrm{AD}$ & HWD & SSD & & $A D$ & HWD & SSD \\
\hline Moisture, wt\% & 30.0 & 9.0 & 8.5 & 7.2 & 22.5 & 10.7 & 9.4 & 4.4 & 37.5 & 8.1 & 9.6 & 11.6 \\
\hline $\begin{array}{l}\text { Hardgrove } \\
\text { Index }\end{array}$ & 21 & $\mathrm{ND}^{2}$ & 69 & 64 & 44 & ND & 65 & 64 & 64 & ND & 74 & 74 \\
\hline \multicolumn{13}{|l|}{ Processing } \\
\hline Friability, $\%$ & ND & ND & 13.4 & 14.3 & ND & ND & 7.1 & 4.6 & $\mathrm{ND}$ & ND & 10.9 & 17.6 \\
\hline Dust Index, \% & ND & ND & 0.7 & 0.4 & ND & ND & 0.6 & 0.2 & ND & ND & 1.1 & 0.4 \\
\hline \multicolumn{13}{|c|}{$\begin{array}{l}\text { Tumbler Test } \\
\text { (2400 revolutions) }\end{array}$} \\
\hline Friability, \% & 6.7 & 14.1 & 20.9 & 37.1 & 7.2 & 26.0 & 33.0 & 39.2 & 7.2 & $\begin{array}{l}37 . \\
4\end{array}$ & 41.1 & 38.4 \\
\hline Dust Index, $\%$ & 0.7 & 2.9 & 6.8 & 13.6 & 1.7 & 7.0 & 6.2 & 10.3 & 1.7 & 6.0 & 10.3 & 7.5 \\
\hline \multicolumn{13}{|l|}{$\begin{array}{l}\text { Drop-Shatter } \\
\text { Test } \\
\text { (10 drops) }\end{array}$} \\
\hline Friability, $\%$ & 3.8 & 13.2 & 20.7 & 26.6 & 10.7 & 33.1 & 26.3 & 40.5 & 5.3 & $\begin{array}{l}35 . \\
6\end{array}$ & 34.8 & 34.2 \\
\hline
\end{tabular}

consequently, the higher tumbling speed $(80 \mathrm{rpm})$ was implemented to test dried coals and to allow testing of more coal samples within the study test period. The appropriate insert dimensions and tumbling speed were established prior to performing tests on sized raw, air-dried (AD), HWD, and SSD samples of Colstrip and Little Tonzona subbituminous coals and Knife River lignite. Revolutions were varied from 1200 to 14,400 in 1200-revolution increments. As an example, Figure 3 illustrates the effects of varying the total revolutions for 100-gram samples of raw, $A D$, HWD, and SSD Colstrip coals. The moisture content of the tumbled samples and the method of drying may both have been factors affecting the level of coal comminution. The AD, HWD, and SSD Colstrip coals, with tumbler-tested moisture contents of $10.7,-9.4$, and $4.4 \mathrm{wt} \%$, respectively, experienced significant reduction of the +6.7 - $\mathrm{mm}$ fractions relative to the raw coal that was tested at $30 \mathrm{wt} \%$ moisture. Table 4 summarizes the sieve analysis, estimated average particle size, and indices for tumble tests completed with Colstrip coal samples. The friability and dust indices calculated in addition to the tumble index are summarized in Table 3 for the three different coal samples. Results reported in Table 4 represent 100-gram tests performed at $80 \mathrm{rpm}$ for 2400 revolutions.

Drop-Shatter. Drop-shatter test results for two- to ten-drop tests on the raw coals indicated that the Little Tonzona friability index varies from 0.7 to 3.8 , while the more friable Colstrip and 


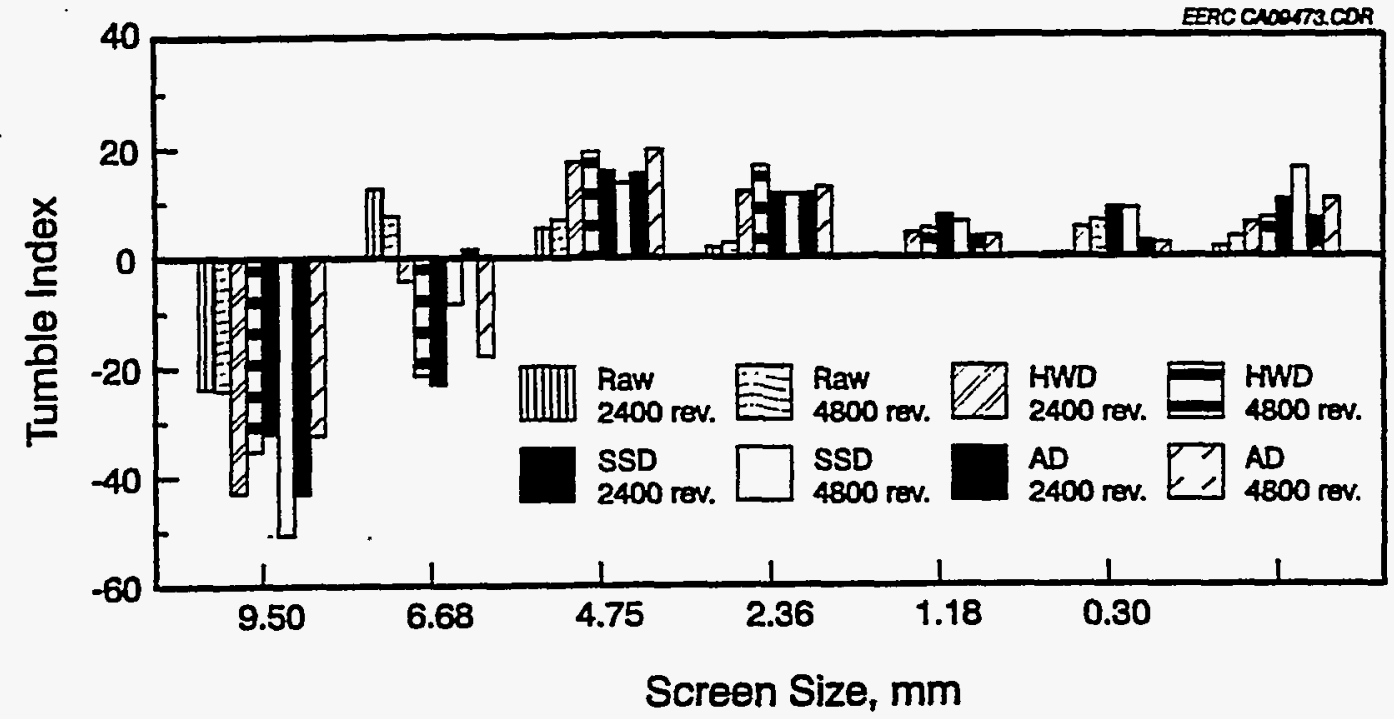

Figure 3. Tumble indices for raw, AD, HWD, and SSD Colstrip as a function of total revolutions.

Knife River coals varies from 2.0 to 10.7 and from 0.5 to 5.3 for two to ten drops, respectively. The friability indices of all dried coals were significantly higher than those of the parent coals, reemphasizing that dried samples are anticipated to be much more susceptible to excessive breakage when handled. Results for the drop-shatter test program are summarized for ten-drop data and presented in Table 5.

Jameson Test Cell. Figures 4 and 5 summarize the results from Jameson tests for raw and treated Colstrip samples tumbled in the ASTM cell for 180 minutes. Figure 4 indicates a dramatic decrease in raw coal moisture content to $9 \mathrm{wt} \%$, while only slight variances in moisture content were observed for the treated samples. Figure 5 represents the amount of fines classified as $-0.8-\mathrm{mm}$ material versus tumbling time for the same three Colstrip samples. This figure indicates that the amount of fines increases substantially for the raw coal as the coal dries, similarly to the treated products. These results indicate that for the three drying methods evaluated, the amounts of fines that were generated were not necessarily process-specific, but relate more closely to the moisture content of the individual fuel.

Results from the testing of Knife River coal, illustrated in Figure 6, indicate that the raw coal generated less fines than the dried fuels. This relationship corresponds well to those results reported previously from tumbler and drop-shatter tests (2). 


\section{TABLE 4}

Summary Information from Tumble Tests Conducted on Various Colstrip Samples

\begin{tabular}{|c|c|c|c|c|c|c|c|c|}
\hline Drying Type: & \multicolumn{2}{|c|}{ Raw } & \multicolumn{2}{|c|}{$\mathrm{AD}$} & \multicolumn{2}{|c|}{ HWD } & \multicolumn{2}{|r|}{ SSD } \\
\hline Moisture, wt\% & \multicolumn{2}{|c|}{22.5} & \multicolumn{2}{|c|}{10.7} & \multicolumn{2}{|c|}{9.4} & \multicolumn{2}{|r|}{4.4} \\
\hline Revolutions & - & 2400 & - & 2400 & - & 2400 & - & 2400 \\
\hline Avg. Size, mm & 10.5 & 9.5 & 10.0 & 7.0 & 9.7 & 6.5 & 9.3 & 5.7 \\
\hline Size, $\mathrm{mm}$ & \multicolumn{8}{|c|}{ Cumulative Weight Percent Retained on Screen } \\
\hline 9.5 & 81.1 & 58.1 & 63.6 & 20.8 & 54.0 & 11.2 & 40.1 & 8.2 \\
\hline 6.68 & 100.0 & 90.0 & 100.0 & 59.2 & 100.0 & 53.8 & 100.0 & 45.3 \\
\hline 4.75 & 100.0 & 95.5 & 100.0 & 74.6 & 100.0 & 71.7 & 100.0 & 61.2 \\
\hline 2.36 & 100.0 & 97.3 & 100.0 & 86.3 & 100.0 & 83.8 & 100.0 & 73.0 \\
\hline 1.18 & 100.0 & 97.7 & 100.0 & 90.1 & 100.0 & 88.3 & 100.0 & 80.7 \\
\hline 0.3 & 100.0 & 98.3 & 100.0 & 93.0 & 100.0 & 93.8 & 100.0 & 89.7 \\
\hline $\begin{array}{l}\text { Friability } \\
\text { Index, } \%\end{array}$ & \multicolumn{2}{|c|}{9.8} & \multicolumn{2}{|c|}{26.0} & \multicolumn{2}{|c|}{33.0} & \multicolumn{2}{|r|}{39.2} \\
\hline Dust Index, \% & \multicolumn{2}{|c|}{1.7} & \multicolumn{2}{|c|}{7.0} & \multicolumn{2}{|c|}{6.2} & \multicolumn{2}{|r|}{10.3} \\
\hline
\end{tabular}

\section{TABLE 5}

Summary Information from Tumbler and Conveyor

Tests Conducted on Raw and Air-Dried Beulah Lignite Samples

\begin{tabular}{|c|c|c|c|c|c|c|c|c|}
\hline & \multicolumn{2}{|c|}{$\begin{array}{l}\text { Raw Beulah } \\
\text { Tumble Test }\end{array}$} & \multicolumn{2}{|c|}{$\begin{array}{c}\text { Conveyor, } \\
5 \mathrm{~min}\end{array}$} & \multicolumn{2}{|c|}{$\begin{array}{l}\text { Air-Dried } \\
\text { Tumble Test }\end{array}$} & \multicolumn{2}{|c|}{$\begin{array}{c}\text { Conveyor, } \\
5 \mathrm{~min}\end{array}$} \\
\hline Moisture, wt\% & \multicolumn{2}{|c|}{32.3} & \multicolumn{2}{|c|}{32.3} & \multicolumn{2}{|c|}{27.3} & \multicolumn{2}{|c|}{27.3} \\
\hline Revolutions & & 2400 & & 10 & & 2400 & & 10 \\
\hline Avg. Size, $\mathrm{mm}$ & 9.4 & 8.8 & $\overline{9.4}$ & 9.1 & 9.3 & 8.2 & 9.3 & 7.6 \\
\hline Size, $\mathrm{mm}$ & \multicolumn{8}{|c|}{ Cumulative Weight Percent Retained on Screen -- } \\
\hline 9.5 & 46.9 & 35.7 & 45.5 & 41.7 & 45.0 & 29.6 & 44.7 & 20.0 \\
\hline 6.68 & 80.6 & 80.6 & 90.6 & 83.5 & 89.0 & 72.5 & 83.6 & 57.4 \\
\hline 4.75 & 100.0 & 96.9 & 100.0 & 95.4 & 100.0 & 90.8 & 100.0 & 83.7 \\
\hline 2.36 & 100.0 & 98.0 & 100.0 & 98.1 & 100.0 & 94.9 & 100.0 & 95.1 \\
\hline 1.18 & 100.0 & 99.0 & 100.0 & 98.9 & 100.0 & 95.2 & 100.0 & 97.6 \\
\hline 0.30 & 100.0 & 99.0 & 100.0 & 99.5 & 100.0 & 96.9 & 100.0 & 99.2 \\
\hline \multicolumn{9}{|l|}{ Friability } \\
\hline Index, \% & \multicolumn{2}{|c|}{6.4} & \multirow{2}{*}{\multicolumn{2}{|c|}{4.2}} & \multicolumn{2}{|c|}{11.9} & \multicolumn{2}{|c|}{18.3} \\
\hline Dust Index, \% & \multicolumn{2}{|c|}{1.0} & & & \multicolumn{2}{|c|}{3.1} & \multicolumn{2}{|c|}{0.81} \\
\hline
\end{tabular}




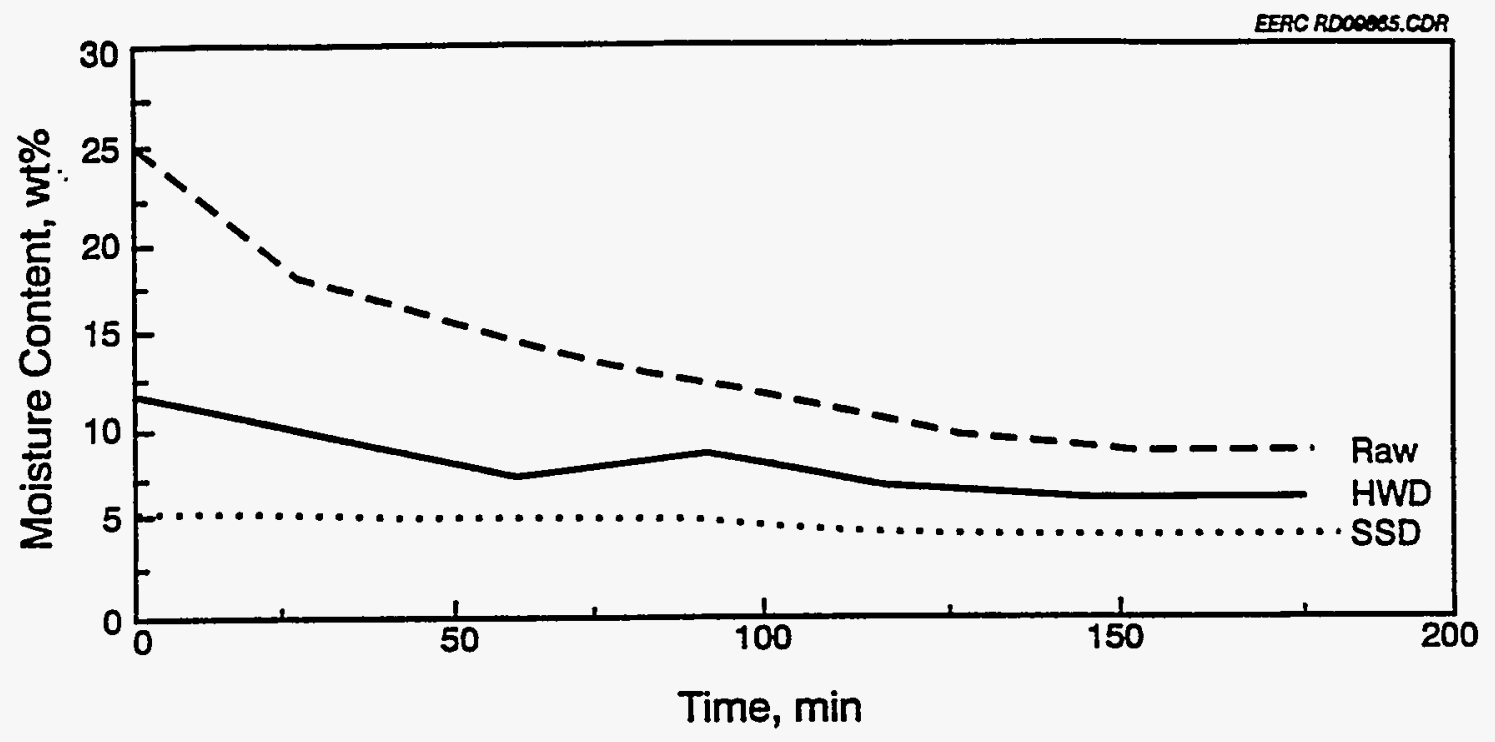

Figure 4. Jameson test resuits, moisture content versus tumbling time, for various Colstrip samples.

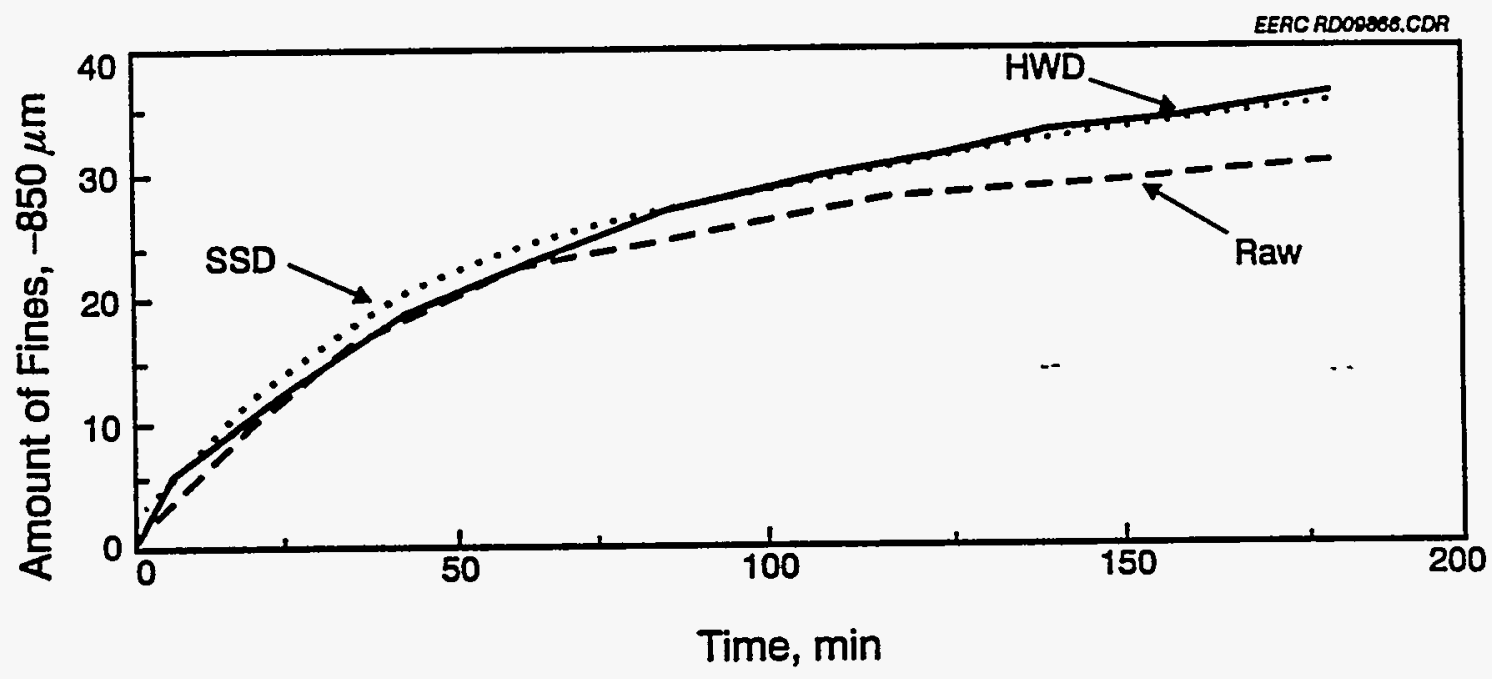

Figure 5. Jameson test results, amount of fines versus tumbling time, for various Coistrip samples. 
A comparison was made between the moisure loss results for the entire duration of Jameson cell testing on the coals. Moisture analysis indicated that for the three coals tested, the total moisture loss for the samples was $16.9 \%$ for Knife River, $15.9 \%$ for Colstrip, and $12.6 \%$ for Little Tonzona over the 180 minutes of Jameson cell testing. These results are within $5 \%-10 \%$ of the air-dried loss at $25^{\circ} \mathrm{C}$ as performed for proximate analysis. In addition, Jameson tests conducted on raw coals also indicated that fines production depends on the relative humidity of the air being pulled by the vacuum. The higher the relative humidity, the less drying occurs to the raw coal, producing less fines.

An additional test was conducted on raw and dried fuels that were originally saturated with water and then tumbled. As Figure 6 illustrates, there was an initial suppression of the dust or fines generated; however, as tumbling continued, the saturated sample generated more fines than the original test sample. Initial moisture contents are indicated in parentheses. These results will be evaluated further to aid in the development of effective water-based dust suppression additives for long distance hauling through a variety of climate conditions.

Conveyor Test. Various laboratory- and pilot-scale durability tests were recently conducted with as-received (32.3 wt\% moisnure) and air-dried (27.5 wt\% moisture) samples of Beulah lignite. The two samples differed by only $5 \%$ in moisture; however, they had substantially different handling characteristics. Raw Beulah lignite sized to $12.5 \times 4.75 \mathrm{~mm}$ was used as the test sample for the conveyor and tumbler testing. The results, summarized in Table 6, illustrate that 5 min of transferring the coal sample with the conveyor test system produced similar screen results to those from a tumbler test using laboratory methods for friability indices. In addition, similarly to results reported earlier on subbituminous coal, an increase of approximately $85 \%$ in friability was caused
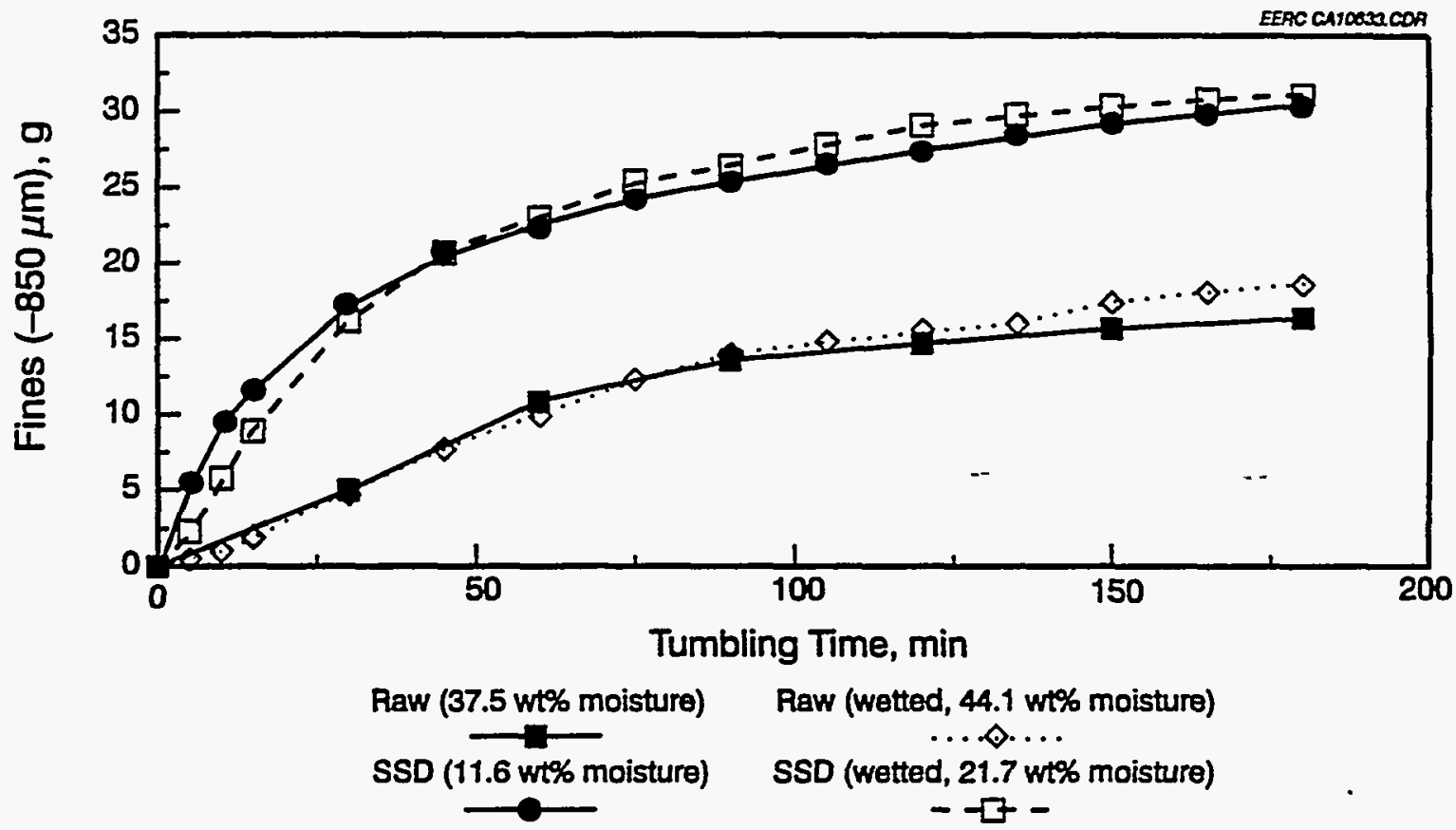

Figure 6. Jameson test results for saturated and unsaturated Knife River samples. 
by air drying. When the laboratory and pilot results are compared, the dust indices were much lower for the conveyor (pilot) tests. Since the dust cannot be contained for the conveyor and thus the total dust cannot be measured, dusting levels are evaluated using a combination of the dry-sieve information and concentrations indicated by real-time aerosol monitor (RAM)- 1 as the coal is dropped. Results from RAM-1, Figure 7, indicate a substantial increase in dust concentration as the coal was dried. When raw and air-dried sample performance were compared, the average dust concentrations increased from 9.9 to $14.4 \mathrm{mg} / \mathrm{m}^{3}$, while the maximum concentration doubled from 11.8 to $23.5 \mathrm{mg} / \mathrm{m}^{3}$. Based on these results, the conveyor test assembly will complement laboratory test procedures in evaluating the durability of solid fuels, including lump coals, aggregated, and agglomeration fuel types.

\subsection{Self-Heating Results}

Using the Bureau of Mines base design, efforts focused on improvements to that system to enhance speed, accuracy, and reliability of self-heating testing while still keeping the unit cost down. Pressure transducers selected for the EERC were Setra ${ }^{\oplus}$ Model C-264 with a 4- to 20-mA output. These pressure transducers can be recalibrated and the span adjusted, whereas the Omega ${ }^{\circ}$ transducers used by the Bureau do not allow for span adjustment and have a tendency to drift. The Omega transducers also depend upon barometric pressure, having a range of 0-20 psig. The Setra transducers have a range of $0-30 \mathrm{~cm}$ of water column for determining pressure and are not affected by barometric pressure. A Genesis software package was used to continuously log pressure indications and present histories for each sample throughout the given test period. Similarly to the

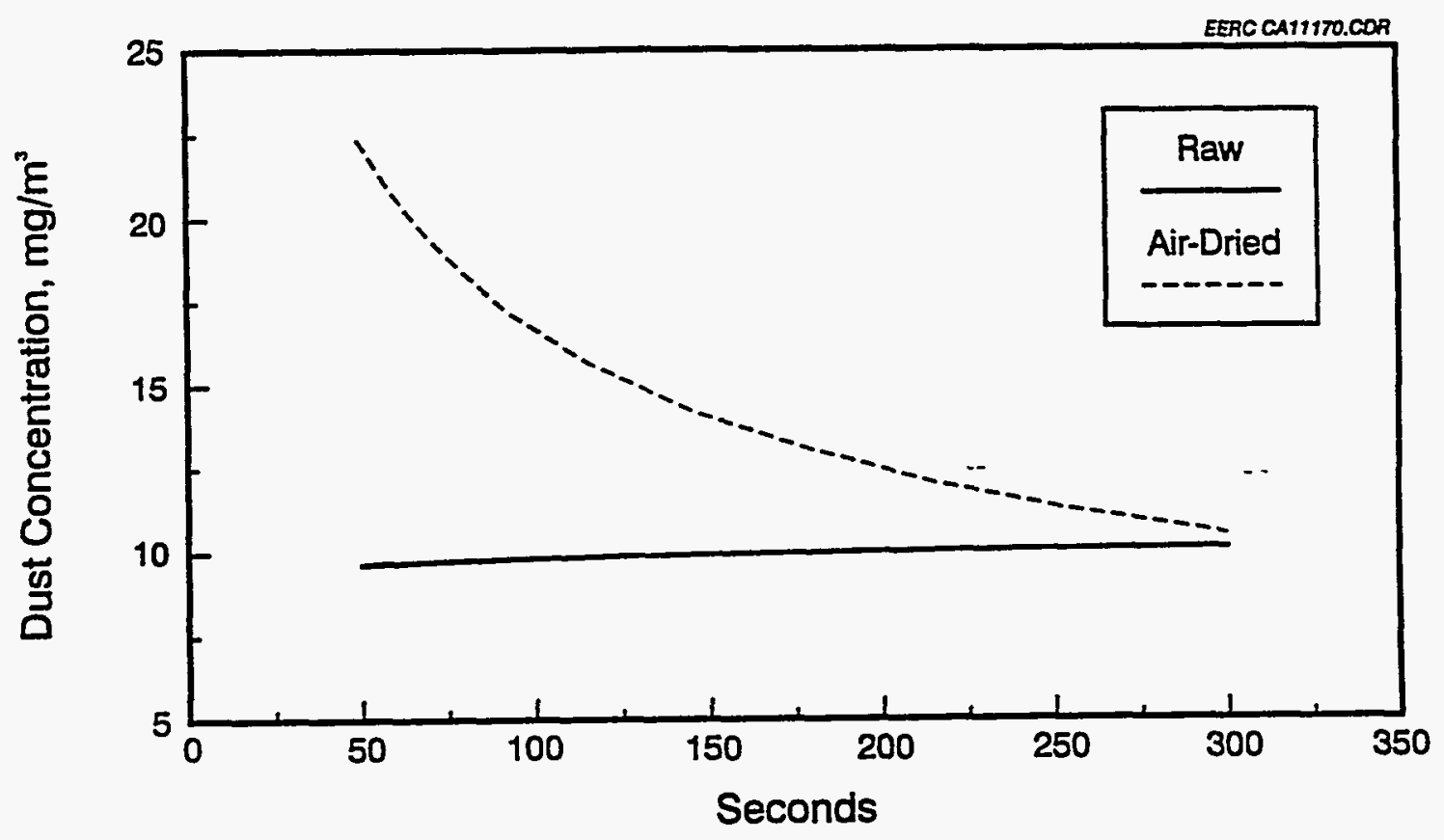

Figure 7. Dust concentration comparison. 
TABLE 6

Summary Information from Tumbler and Conveyor

Tests Conducted on Raw Beulah Lignite Samples

\begin{tabular}{|c|c|c|c|c|c|c|c|c|}
\hline & \multicolumn{2}{|c|}{ Tumbler Test } & \multicolumn{2}{|c|}{$\begin{array}{c}\text { Conveyor, } \\
15 \mathrm{~min}\end{array}$} & \multicolumn{2}{|c|}{$\begin{array}{c}\text { Conveyor, } \\
30 \mathrm{~min}\end{array}$} & \multicolumn{2}{|c|}{$\begin{array}{c}\text { Conveyor, } \\
60 \mathrm{~min}\end{array}$} \\
\hline Moisture, wt\% & \multicolumn{2}{|c|}{32.3} & \multicolumn{2}{|c|}{32.3} & \multicolumn{2}{|c|}{32.3} & \multicolumn{2}{|c|}{32.3} \\
\hline Revolutions & $\ldots$ & 2400 & 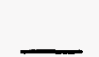 & 30 & 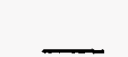 & 60 & 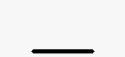 & 120 \\
\hline Avg. Size, mm & 9.4 & 8.7 & 9.7 & 8.3 & 9.0 & 7.1 & 9.1 & 5.4 \\
\hline Size, $\mathrm{mm}$ & \multicolumn{8}{|c|}{ Cumulative Weight Percent Retained on Screen } \\
\hline 9.5 & 46.5 & 35.0 & 55.1 & 30.2 & 36.0 & 11.9 & 37.3 & 3.7 \\
\hline 6.68 & 90.6 & 79.3 & 91.8 & 72.0 & 83.1 & 50.0 & 84.2 & 27.1 \\
\hline 4.75 & 100.0 & 95.5 & 100 & 89.8 & 100.0 & 80.3 & 99.9 & 55.6 \\
\hline 2.36 & 100.0 & 97.0 & 100 & 95.6 & 100.0 & 92.5 & 100.0 & 79.2 \\
\hline 1.18 & 100.0 & 98.0 & 100 & 97.3 & 100.0 & 95.0 & 100.0 & 85.9 \\
\hline 0.30 & 100.0 & 99.0 & 100 & 99.3 & 100.0 & 98.7 & 100.0 & 96.6 \\
\hline \multicolumn{8}{|l|}{ Friability } & 40.9 \\
\hline Dust Index, \% & \multicolumn{2}{|c|}{1.0} & \multicolumn{2}{|c|}{0.7} & \multicolumn{2}{|c|}{1.3} & \multicolumn{2}{|c|}{3.5} \\
\hline
\end{tabular}

Bureau of Mines testing, gas chromatography (GC) testing will be done on a sample of the gas removed from the glass container to determine the major gases produced during self heating. Gas will be analyzed using a Hewlett-Packard ${ }^{\oplus}$ Model 5880 a GC with a refinery gas analyzer package to detect selected gases in process gas samples.

Preliminary testing will consist of processing raw and value-added coal samples. Effects of particle size, moisture content, and other variables may be investigated as deemed necessary. The coarse samples will be pulverized, as needed, in a grinding mill and then sieved to obtain the desired size fractions. Additional sample preparation will include drying the samples to constant weight in a continuously nitrogen-purged oven set at $67^{\circ} \mathrm{C}$. Predrying will be conducted to help minimize diffusion and exchange phenomena of carbon dioxide observed with LRCs." It has been shown that for LRCs, the moisture content of the coal is directly related to its carboxyl content, and these oxygen-containing groups can exert a controlling influence on the adsorbed water (14). Initial testing conducted indicated a need for an improved method of sample containment after drying. Test methods recently developed at the U.S. Department of Energy Pittsburgh Energy Technology Center (PETC) also indicated a need to minimize sample exposure to atmosphere. In addition, methods development may also include exposure of the dried samples to pure $\mathrm{O}_{2}$ to speed up the self-heating process (15). 


\subsection{Moisture Reabsorption Results}

Equilibrium moisture determination tests, using ASTM and modified procedures, were performed on raw, AD, HWD, and SSD samples of Colstrip and Little Tonzona Creek subbituminous coals and on the Knife River lignite. The moisture contents of the coals ( -60 mesh) attained after 3 days of incubation (ASTM specifications) are presented in Table 7. Notable results are significant reductions in moisture holding capacity for all three coals; saturated-steam drying had a somewhat greater effect on reducing the moisture reabsorption capabilities of the coals. Air drying also apparently caused sufficient coal changes, possibly pore collapse, to prevent moisture reabsorption to the levels of the raw coals.

\section{TABLE 7}

Equilibrium Moisture Results

\begin{tabular}{|c|c|c|c|c|}
\hline \multirow[t]{2}{*}{ Fuel Type } & \multicolumn{2}{|c|}{$\begin{array}{c}\text { ASTM } \\
(1.18 \mathrm{~mm} \times 0 \text { in.) } \\
\end{array}$} & \multicolumn{2}{|c|}{$\begin{array}{c}12.7 \times 6.7 \mathrm{~mm} \\
\text { (no size reduction) }\end{array}$} \\
\hline & 3-Day & Extended & Saturated & Unsaturated \\
\hline \multicolumn{5}{|l|}{ Knife River } \\
\hline Raw & 37.1 & 35.1 & 38.5 & 35.1 \\
\hline Air-Dried & 32.3 & 28.2 & 33.8 & 24.3 \\
\hline Hot-Water-Dried & 19.4 & 15.0 & 12.8 & 11.9 \\
\hline Steam-Dried & 14.3 & 12.6 & 14.8 & 14.4 \\
\hline \multicolumn{5}{|l|}{ Colstrip } \\
\hline Raw & 25.7 & 25.3 & 25.7 & 25.3 \\
\hline Air-Dried & 20.7 & 20.6 & 23.6 & 21.5 \\
\hline Hot-Water-Dried & 9.6 & 9.3 & 10.0 & 10.7 \\
\hline Steam-Dried & 8.4 & 8.6 & 7.3 & 7.0 \\
\hline Little Tonzona & & & - & $-\cdot$ \\
\hline Raw & 34.0 & 31.0 & 30.4 & 30.6 \\
\hline Air-Dried & 20.4 & 26.4 & 30.2 & 25.1 \\
\hline Hot-Water-Dried & 22.8 & 11.1 & 10.8 & 10.4 \\
\hline Steam-Dried & 18.4 & 9.5 & 9.4 & 8.7 \\
\hline
\end{tabular}

The results of preliminary tests to observe the effect of sample preparation on equilibrium moisture values are also presented in Table 5. The raw, HWD, and SSD samples of Knife River 
lignite and Little Tonzona and Colstrip subbituminous lump coals, incubated for three days without prior saturation, achieved equilibrium moisture values similar to those for the samples presaturated via the ASTM procedure. The effect of particle size on equilibrium moisture was more difficult to assess. Most of the forms for the Knife River and Colstrip coals attained similar equilibrium moistures after 3 days of incubation, regardless of coal size. Similar agreement was not achieved with the Little Tonzona coal, in which the HWD-and SSD-lump-coal equilibrium moistures were considerably lower than their for fine-coal counterparts. In general, no particular coal form exhibited consistency of equilibrium moisture regardiess of coal size. The results do indicate the necessity for similar size and preparation methodology in testing coal properties.

\subsection{CONCLUSIONS}

This report presents data for three raw coals and dried coal products analyzed by various strength and stability test methods. The results show that as the moisture content is decreased, the amount of generated dust substantially increased to levels viewed as unacceptable by industry (i.e., fines less than $0.5 \mathrm{~mm}$ not to exceed $10 \mathrm{wt} \%$ ) (16). Additional findings were as follows:

- Slightly dried LRCs are much more friable than bituminous coals because of surface fracturing caused by slacking.

- 5-min conveyor tests yield comparable results to those from laboratory procedures.

- The conveyor test offers a test procedure for use with larger coal volumes and an environment to review the effectiveness of dust suppression techniques.

- Tests performed to evaluate the tendency for moisture reabsorption of dried LRCs indicated that coals tend to reabsorb the moisture during air drying, whereas hydrothermal treatment processes do not allow reabsorption.

Through development of these laboratory techniques, better predictions for the effects that transport, handling procedures, and climate have on the stability of dried LRCs are anticipated. This is extremely important when the virtues of a particular western coal type are marketed, as the coal is transported long distances to eastern or foreign markets. If commercial drying of LRCs is to be successful, efforts must continue to develop stability analysis and cost-effective, stable products.

\subsection{FUTURE WORK}

- Continue to correlate laboratory durability test results with those from the conveyor tests as they apply to commercial coal-handling operations. Complete test matrix with coal samples of various coal ranks and drying times. Arrange portable fans at various locations with the loop to simulate wind and its drying effects.

- Establish grindability database from U.S. Bureau of Mines information (17).

- Correlate grindability with durability results. 
- Obtain dust-suppressant additive(s) and develop test protocol for evaluation.

- Initial evaluation of self-heating tendencies on selected coal samples will be correlated with results from Bureau of Mines testing on bituminous coals.

- Equilibrium moisture testing at various temperatures and a constant relative humidity will be performed on raw and value-added samples.

\subsection{REFERENCES}

1. Grimes, W.R.; Cha, C.; Sheesley, D. "Future Research Needs of Western Coal," In Proceedings of the 6th Annual Coal Preparation, Utilization, and Environmental Control Contractors' Conference, Pittsburgh, PA, Aug. 1990; pp 267-274.

2. Yancey, H.F.; Johnson, K.A.; Selvig, W.A. "Friability, Slacking Characteristics, LowTemperature Assay and Agglutinating Value of Washington and Other Coals," Technical Paper No. 512; U.S. Bureau of Mines, 1932.

3. Leonard, Joseph W., III, Ed. In Coal Preparation; Society for Mining, Metallurgy, and Exploration, Inc.: Littleton, CO, 1991; p 37.

4. Parry, V.F.; Goodman, John B. "Storage of Subbituminous Coal in Bins," Report of Investigations No. 3587; U.S. Bureau of Mines, 1941.

5. Fieldner, A.C.; Selvig, W.A.; Frederick, W.H. "Accelerated Laboratory Test of Slacking Characteristics of Coal," Report of Investigations No. 3055; U.S. Bureau of Mines, 1930, $24 \mathrm{p}$.

6. Couch, G.R. IEA Coal Research Reference: Lignite Upgrading; May 1990.

7. Willson, W.G.; Young, B.C.; Irwin, W. "Low-Rank Coal Drying Advances," Coal 1992, $97(8), 24-27$.

8. Parry, V.F.; Harrington, L.C.; Koth, A. "The Preparation of Stable Non-Slacking Fuel by Steam Drying Subbituminous Coal and Lignite," Trans. ASME 1942, 64 (3), 177-183.

9. American Society for Testing and Materials. "Gaseous Fuels: Coal and Coke," Philadelphia, PA, 1992; Vol. 05.05.

10. Farrugia, T.J.; Ahmed, N.; Jameson, G.J. "A New Technique for Measuring Dustiness of Coal, "Journal of Coal Quality 1989, 2, 55.

11. Smith, A.C.; Lazarra, C.P. "Spontaneous Combustion Studies of U.S. Coals," Bureau of Mines RI 9079; 1987, 28 p.

12. Miron, Y.; Smith, A.C.; Lazarra, C.P. "Sealed Flask Test for Evaluating the Self-Heating Tendencies of Coals," Bureau of Mines Report of Investigations No. 9330; 1990, 18 p. 
13. Miron, Y. "Construction and Operation of a Sealed Flask Unit to Assess the Self-Heating Tendencies of Coal," Bureau of Mines Report of Investigations No. 4913, 1993, 13 p.

14. Schafer, H.N.S. "Factors Affecting the Equilibrium Moisture Contents of Low-Rank Coals," Fuel 1972, 51 (1), 4-9.

15. Fauth, D. "Spontaneous Combustion of Low-Rank Coal," Presented at 10th Annual Coal Preparation, Utilization, and Environmental Control Contractors; Conference, Pittsburgh Energy Technology Center, July 1994.

16. Idemitsu Kosan Co. Ltd., Japan. "Optimizing the Quality of Australian Coal for Japanese Customers: Prevention of Handling Problems," In Proceedings of the 5th Australian Coal Science Conference, Melbourne, Australia, Nov. 1992; pp 249-256.

17. Gomez, M.; Hazen, K. "Prediction of Coal Grindability from Exploration Data," Report of Investigations No. 7421; U.S. Bureau of Mines, 1970. 


\section{APPENDIX A}

\section{ASTM AND OTHER PROCEDURE DESCRIPTIONS}




\section{ASTM AND OTHER PROCEDURE DESCRIPTIONS}

Currently five American Society for Testing and Materials (ASTM) procedures are used to address the physical stability of the coal or coal-derived product. ASTM procedure D1412-86 to determine equilibrium moisture is an adequate procedure to assess moisture readsorption for low-rank coals (LRCs) and upgraded LRCs, provided that the test is carried out over sufficient time to ensure that the sample has indeed equilibrated, which sometimes can exceed a week's duration. For determination of the handleability of coal and coal-derived products in terms of dust generation, ASTM D547-41 dusting index , ASTM D441-45 tumble method, ASTM D409-71 Hardgrove index, and ASTM D440-49 drop-shatter test are used.

\section{EQUILIBRIUM MOISTURE (ASTM D412-86)}

The ASTM D1412 equilibrium moisture procedure consists of first slurrying the coal sample in water and mixing the slurry for $3 \mathrm{hr}$. The mixture is then dewatered and placed in a cabinet where conditions are maintained under vacuum at $30^{\circ} \mathrm{C}$ and $96 \%$ to $97 \%$ relative humidity. The humidity is maintained by a saturated potassium sulfate $\left(\mathrm{K}_{2} \mathrm{SO}_{4}\right)$ solution. The final moisture at "equilibrium" is an average of three samples, determined by weight loss at $105^{\circ} \mathrm{C}$. The standard test recommends an incubation period of 72 hours ( 3 days) for lignitic and subbituminous coals.

The applicability of the suggested 3-day period was evaluated by extending the incubation period an additional 24 hours to determine whether further weight loss occurred. After 72 and 96 hours of incubation, the sample weight and weight loss were determined. The final moisture content was determined according to normal procedure only after 96 hours.

\section{MODIFIED ASTM EQUILIBRIUM MOISTURE}

- Ten samples of near equal weight $(\sim 5 \mathrm{~g}$ each) were prepared and then weighed to the nearest ten-thousandth of a gram.

- The moisture contents of two samples were determined by heating to constant weight in a $105^{\circ} \mathrm{C}$ oven. An average moisture content was calculated from these two samples. The initial moisture contents of the remaining eight samples were assumed to be equivalent to this average. The solid contents (mass) for each of the remaining eight samples were calculated using the average moisture value. The solids mass in each of these samples was assumed to be unchanged during subsequent incubation.

- The remaining eight samples were incubated for $72 \mathrm{hr}$ at $30^{\circ} \mathrm{C}$ and $96 \%$ to $97 \%$ relative humidity, the humidity being maintained by a saturated potassium sulfate solution. All eight samples were weighed to determine mass loss gain, and a new moisture content was calculated assuming the mass change was due to moisture loss or gain only. An average moisture content was determined from these eight samples; this average value is called the calculated moisture content. The actual moisture contents of two samples were determined by heating to constant weight in a $105^{\circ} \mathrm{C}$ oven. An average moisture content 
was determined from these two samples; this average value was called the measured moisture content.

- The remaining six samples were incubated for an additional 48 hours, resulting in a cumulative incubation period of 120 hours ( 5 days). Again calculated and measured moisture contents were determined. This procedure was repeated after 168 hours ( 7 days) and 240 hours (10 days) of cumulative incubation. The entire test procedure was done on Day 10 as the last two samples were consumed during measurement of the final moisture content. Calculated and measured moisture contents were determined after each of these additional incubation periods.

\section{DUSTINESS TEST (ASTM D547-41)}

The ASTM procedure designates that a 5-ft dust cabinet cell $\left(6 \mathrm{ft}^{3}\right.$ volume) be used to study the dust generated from dropping a coal sample $4 \mathrm{ft}$. The top foot of the cell is used to load $50 \mathrm{lb}$ of the air-dried test coal onto a top slide plate. No size for the coal is specified for this test. Once the coal has been loaded, the top slide plate is removed. After a 5-sec delay, two lower slide plates are inserted at the 2 - $\mathrm{ft}$ level. The first slide plate is removed after $2 \mathrm{~min}$. The amount of material that has settled on the slide plate is weighed and multiplied by an estimated density of the coal. This material is called the coarse dust. After $10 \mathrm{~min}$, the second slide plate is removed and weighed. Again, the weight is multiplied by the density, categorized, and called float dust. The results are then reported as coarse and fine dust ratings. Average results for the test coals are determined acceptable when they fall within $20 \%$.

\section{TUMBLE TEST (ASTM D441-45)}

The tumble test covers the determination of the relative friability of a particular size of sized coal. It affords a means to measure the liability of coal to break into smaller pieces when subjected to repeated handling at the mine or subsequently by the distributor or by the consumer. The test is useful for ascertaining the similarity of coals with respect to friability caused by abrasion. This method also may serve to indicate the relative extent to which sized coals will suffer size degradation in certain mechanical feed devices. The test may be employed for differentiating between certain ranks and grades of coal, and therefore the method is of service for coal classification purposes.

The tumble test involves using a cylindrical steel cell with internal diameters of $7.25 \mathrm{in}$. by 7.25 in. deep and $1 / 4$ in. thick. An insert with three ledges is used to aid the tumbling or mixing of the coal. The dimensions of the insert are $6.5 \times 3 / 4 \times 1 / 8 \mathrm{in}$. with $\%$-in. clearance between the outer edge and the outside ring. This unit is designed for 1000 grams of $1.5 \times 1.06$-in. coal sample. For tumbling, the jar is lain in a horizontal position in a suitable support or rack and rotated about its cylindrical axis at the rate of $40 \mathrm{rpm}$ for 60 minutes, or 2400 total revolutions. The coal is tumbled, then sized using wire screens of various sizes, ranging from 1.06 to 0.75 in. Calculations are based upon size distributions and the amounts that collect on each screen. From the screen analysis, the friability index and dust index are calculated to report the durability of the coal material. The dust index is determined by the weight percent that is below $\mathbf{5 0}$ mesh, while the 
friability index is calculated using screening data and a size factor (calculated by various weight fractions from the screening results).

\section{MODIFIED TUMBLER TESTING}

The basic procedures for loading the coal, size determinations, and indices calculation remain similar to the ASTM procedure. However, the existing method for tumbling could not be used for the upgraded low-rank coal product since the ASTM requires the coal size to be $38.1 \times$ $26.5 \mathrm{~mm}$ and all of the coal products were $12.7 \times 4.75 \mathrm{~mm}$. Therefore, all design efforts on the tumbler cell, such as the flights used to provide adequate mixing action during tumbling, are based upon the larger-size coal. The test program examined the difference between using the existing dimensions of the flights versus readjustment of the flights to the size of the coal, namely reducing the gap between the ledge and the edge of the cell from $15.9 \mathrm{~mm}(\% / \mathrm{s}$ in.) to approximately $3.18 \mathrm{~mm}(1 / \mathrm{s}$ in.). This flight setup or insert will be referred to as the "new" insert in the text of this report. Figure A-1 indicates the sizes of the two different inserts used for tumbler testing.

The amount of coal used was $100 \mathrm{~g}$ (versus $1000 \mathrm{~g}$ in the ASTM methods) to utilize appropriately the small amount of product material that is generated from bench-scale autociaves. Another change to the ASTM procedures was increasing the rpm level from 40 to 80 in order to provide more testing within a shorter time frame. Preliminary tests indicated no significant difference between 40 and $80 \mathrm{rpm}$ for the same amount of total revolutions.

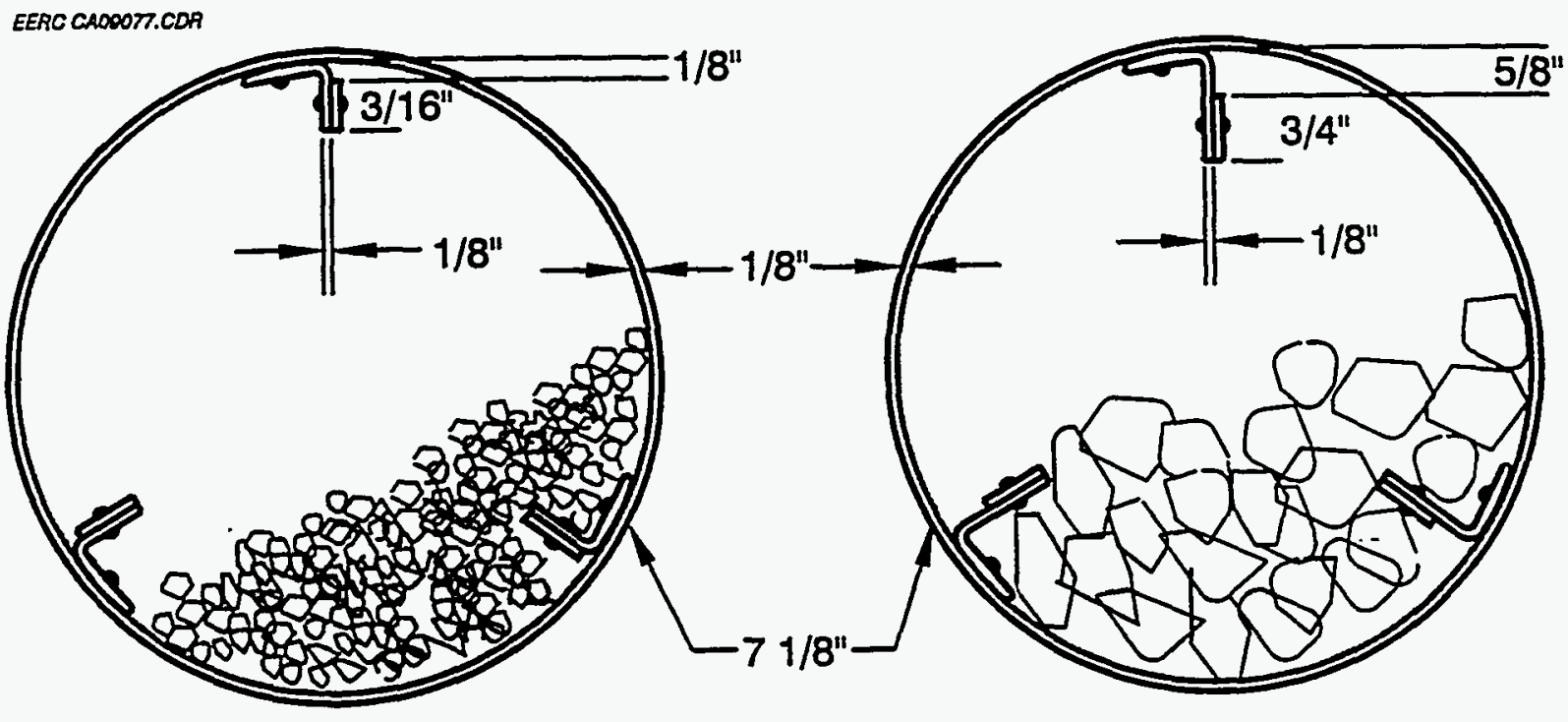

Designed for $12.7-\times 6.68-\mathrm{mm}$ coal

Designed for $38.1-\times 26.5-\mathrm{mm}$ coal

Figure A-1. ASTM vs. Modified tumbler cell design. 


\section{HARDGROVE GRINDABILITY (ASTM D409-71)}

The Hardgrove grindability test is a standard procedure utilized in evaluating coals for the dust program. It is the most widely used measure for ascertaining the relative ease of size reduction of coals and is determined by comparing size-reduction characteristics in laboratory test apparatus of specified design. Grindability is used for determining how much energy input is required for grinding and/or pulverizing coals. The index is beneficial for analyzing the dustiness of the selected coals.

Briefly the procedure is as follows: a 50-g sample of coal, $1.18 \times 0.6 \mathrm{~mm}$ in size $(16 \times 30 \mathrm{mesh})$, is prepared and placed in the standard Hardgrove test apparatus. The test machine is designed to subject the sample to the grinding action of eight 25.4-mm (1-in.) steel balls, which revolve in a lower stationary container and are driven by an upper rotating ring carrying a weight of $29.1 \mathrm{~kg}(64 \mathrm{lb})$. The upper ring is rotated for 60 revolutions. The sample is then removed from the Hardgrove machine and screened on a 75- $\mu \mathrm{m}$ (200-mesh) screen. The Hardgrove grindability index is based on the amount of minus $75-\mu \mathrm{m}$ material produced. Under the standard procedure, this quantity is calculated by difference between the weight of sample placed in the test apparatus $(50 \mathrm{~g})$ and the weight of material retained on the $75-\mu \mathrm{m}$ screen.

\section{DROP-SHATTER TEST (ASTM D440-49)}

This method of drop-shatter testing covers the determination of the relative size stability and its complement, the friability, of sized coal. It affords a means of indicating the ability of coal to withstand breakage when subjected to handling at the mine and during transit to the consumer. The test is useful for ascertaining the similarity of coals with respect to size stability and friability rather than for determining values within narrow limits in order to emphasize their dissimilarity. This method is considered applicable for testing a selected size of different coals, for testing different single sizes of the same coal, and for mixed sizes of the same or different coals.

This test appears best-suited for measuring the relative resistance to breakage of the larger sizes of coal when they are handled in thin layers such as from loader to mine car, from loading boom to railroad car, and from shovel to chute. While it may not be so well adapted for measuring the liability to breakage of coal when handled in mass, it is believed that the test method will serve also to indicate the relative size stability of composite sizes of coal where in commercial handling the smaller-sized pieces have a cushioning effect that tends to lessen the breakage of the larger pieces of coal.

The physical dimensions of the box that holds the coal are 18 in. wide, 28 in. long, and approximately 15 in. deep, supported above a mounted cast-iron steel plate not less than $1 / 2$ in. thick. The inside of the bottom should be $6 \mathrm{ft}$ above the plate. Round screens $8,6,4,3,2,1 \frac{1}{2}$, $1,3 / 4,1 / 2,1 / 4$, and $1 / 8$ in. in diameter will be used to size the coal. The accepted size for procedure D440-49 is 4- to 6-inch coal. 50-lb samples of coal are loaded into the box and dropped twice. Two separate triais are conducted, with results acceptable when within $2 \%$ of each otherApril 28 , 1995. Friability is defined in a manner similar to that of the tumble test. 


\section{Original \\ Camera Ready Copy}

